\title{
Esoteric Writing through Historical Allusions
}

\section{Qu Xuanying's Poetry under Japanese Occupation}

\author{
Chiu Yi-hsuan \\ Research Institute for the Humanities and Social Sciences, \\ Ministry of Science and Technology, Taipei, Taiwan \\ chiuyhs@ntu.edu.tw
}

\begin{abstract}
This paper investigates the poetry of Qu Xuanying, a literatus who remained in the city of Beiping (now Beijing) following its occupation by the Japanese in 1937. Through historical allusions in his poetry, Qu communicated with friends about the ethical dilemmas that he faced under occupation, and reflected upon the choices that literati in earlier eras had made when facing dynastic transitions and foreign conquest. Qu's 'esoteric writing' during the occupation contained a complex set of historical allusions which referenced various points in the Chinese past. Since Qu served in the collaborationist north China regime, he has often been perceived as a 'traitor' or a 'collaborator'. Through this in-depth analysis of his literary works, however, this paper seeks to reveal the special exegetical strategies adopted by literati such as Qu under occupation.
\end{abstract}

\section{Keywords}

Qu Xuanying - occupation - collaboration, Beiping (Beijing) - literati - poetry

\section{Introduction: Living with 'the Enemy' and Esoteric Writing}

In July 1937, the ancient city of Beiping (now Beijing) was filled with a highly tense atmosphere-like a pressure cooker that was about to burst. People were aware that a historical turning point was approaching, but they could not predict what would happen next. An undeclared Sino-Japanese war was about to break out. 
Written accounts of the city produced by Beiping-based literati at that time provide us with an 'in-city perspective'. From the eve of the Japanese invasion to the entry of the Japanese army into the city, the entire city of Beiping was sealed up. This remained the case until the opening of the Beiping-Tianjin Railway on 5 August. With a lack of news from the outside world and the future in doubt, some residents eventually chose to escape the city in early August, going into exile in China's hinterland. Others, however, decided to stay behind and live with the enemy.

Since the Vichy leader Philippe Pétain (1856-1951) used the word 'collaboration' to define French political cooperation with France's German occupiers in 1940, the meaning of this term has gradually become fixed in Western academia. In the Sinophone world, however, there are actually two different ways to translate the term 'collaboration', presenting two different perspectives and exegetical strategies. The first of these terms, tongdi 通敵, literally means 'association with the enemy'. In this sense, 'collaboration' (as tongdi) is regarded as collusion with enemy forces. However, this translation limits the reader's understanding of such acts to collusion and betrayal, thereby obscuring the grey area within which the vast majority of people-who simply waited for appropriate moments to take action-lived. ${ }^{1}$ Less morally laden terms, such as xieli 協力 ('working together') and hezuo 合作 ('cooperation'), are thus also used to translate the English term 'collaboration'2 These translations place more emphasis on the process of coordination and cooperation that was experienced between local elites and a belligerent occupant.

The special spatial and temporal context of occupation had an impact on many people's original understanding of notions such as 'enemy' and 'self', as the boundary between these two categories was loosened. Therefore, in order to probe the true meaning of literary works composed under occupation, we should not only view such works from the perspective of their literal deno-

1 For more discussion on this topic, see David Barrett, 'Introduction: Occupied China and the limits of accommodation', in Chinese Collaboration with Japan, 1932-1945: The Limits of Accommodation, eds David Barrett and Larry N. Shyu (Stanford, CA: Stanford University Press, 2001), 17-18.

2 For more discussion on the translation, see the Chinese translations of Timothy Brook's monograph Collaboration: Japanese Agents and Local Elites in Wartime China (Cambridge, MA: Harvard University Press, 2005): Tongdi: Erzhan Zhongguo de Riben tewu yu difang jingying 通敵：二戰中國的日本特務與地方菁英 (Colluding with the Enemy: Japanese Agents and Local Elites in China during wwII), trans. Lin Tiangui 林添貴 (Taipei: Yuanliu chuban gongsi, 2015); and Timothy Brook, Zhixu de lunxian: Kangzhan shiqi de Jiangnan wucheng 秩序的淪陷：抗戰時期的江南五城 (The Collapse of Order: Five Cities in the Jiangnan Region of China during the War of Resistance), trans. Pan Min 潘敏 (Beijing: Shangwu yinshuguan, 2015). 
tations; we also need to take into account the esoteric connotations behind these texts. As Leo Strauss suggests, under particular historical circumstances, the danger of persecution obliges authors to exercise the art of 'esoteric writing', which in turn demands the reader to read 'between the lines.. ${ }^{3}$ Under the enemy occupation, when discourses on moral choices were polarised, anyone daring to defend accommodation or sheer survival would be suspected of treason. With regard to the danger of moral persecution, literary works composed under such historical circumstances must often be read between the lines, to detect traces of subtle expression and obscure information. ${ }^{4}$ Various rhetorical and linguistic strategies could be employed to express those emotions and memories that could not (and should not) be expressed. If writers could extract accumulated meanings from cultural codes, they could find an exegetical space for their texts, similar to 'esoteric writing'. Historical allusions include clues that readers can use to unravel writers' circumstances under occupation (based on the examples of their predecessors from the past). Indeed, this technique also enabled writers to construct a safe space of 'elusive language' through literary creativity. ${ }^{5}$ It also enabled writers to reveal subtle meanings to specific readers, while at the same time evading the strict censorship that existed under occupation. Such 'esoteric writing', employed to reflect writers' inner thoughts, is therefore key to interpreting a particular kind of classical-style poetry that was written in Japanese-occupied China.

Of all the literati who chose to stay in Beiping, the case of Qu Xuanying 翟 宣穎 (1894-1973) is special. Qu never even considered escaping to the hinter-

3 Leo Strauss, Persecution and the Art of Writing (Chicago: University of Chicago Press, 1988), 24-25. See also: Arthur M. Melzer, Philosophy Between the Lines: The Lost History of Esoteric Writing (Chicago: University of Chicago Press, 2014).

4 As also proposed in Yuan Yidan 袁一丹, 'Yinwei xiuci: Beiping lunxian shiqi wenren xuezhe de biaoda celüe’ 隱微修辭：北平淪陷時期文人學者的表達策略 (Esoteric writing: the literati and scholars' strategies of expression in occupied Beiping), Zhongguo xiandai wenxue yanjiu congkan 中國現代文學研究叢刊 (Modern Chinese Literature Studies) 1 (2014): 1-18; Yuan Yidan, 'Yidai tongshi yu yimin nitai' 易代同時與遺民擬態 (The contemporaneity of dynastic changes and the mimicry of remnant loyalists), Wenxue pinglun 文學評論 (Literature Review) 3 (2015): 81-91.

5 As Asami Yōji 浅見洋二 argues in his study of Chinese literature, the formation of this universal literary writing technique of 'elusive language' is rooted in the conflicts between the literati's speeches, as well as literary activities and the ruling power consequently forcing the literati to compose literary works by applying 'elusive language' techniques such as souci 度 詞 and yinyu 隱語 ('concealed words'). See Asami Yōji, Wenben de mima: Shehuiyujing zhong de Songdai wenxue 文本的密碼：社會語境中的宋代文學 (Textual Codes: Song Literature in Social Context), trans. Li Gui 李貴, Zhao Ruirui 趙芯芯芯 et al. (Shanghai: Fudan daxue chubanshe, 2017), 64-66. 
land, but accepted the fall of Beiping as a fait accompli. His communication with Huang Jun 黃㵝 (189o-1937), to be examined below, is precious because it implies that his accommodation was an active political choice. This was unique among the literati collaborators. Qu Xuanying did not passively subject himself to the transition of power, but rather weighed the alternatives and remained proactive under difficult circumstances. His real intentions, moreover, were encoded in the esoteric writing of poetry. Qu was also unlike Zhou Zuoren 周作 人 (1885-1967), who similarly chose to stay (albeit not without inner struggles) but would not defend his act of collaboration, seeing all self-defence as vulgar. ${ }^{6}$ Qu Xuanying's classical-style poems, especially those serialised in the monthly Concordia (Zhonghe 中和), are precious records in revealing the mentality of the literati under the occupation. ${ }^{7}$ Using abundant historical allusions, Qu's poetry implies his rejection of the polarised view of resistance versus surrender. Instead, it hints at a possible third option. The art of classical-style poetry writing becomes Qu's coded self-defence. Living with the enemy was complicated but, perhaps precisely for this reason, literary production under the occupation occupies a multidimensional and sophisticated exegetical space.

\section{$2 \quad$ A Letter-Poem from a Besieged City}

When Beiping was under siege in 1937, Huang Jun, a literatus living in Nanjing, received a letter-poem from the besieged city. The writer of the letter-poem, $\mathrm{Qu}$ Xuanying — a close friend of Huang - would become one of the Beiping literati who took up a so-called 'illegitimate office' in the Provisional Government of the Republic of China (PG ROC) 'client regime' in north China, controlled by the Japanese military. ${ }^{8}$ When Qu later sorted through his own poems, he titled the

6 For more on Zhou Zuoren's attitude on self-defence, see Huang Kaifa 黃開發, Zhou Zuoren de jingshen xiaoxiang 周作人的精神当像 (A Spiritual Portrait of Zhou Zuoren) (Shenyang: Liaoning renmin chubanshe, 2015), $38-55$.

7 Qu Xuanying thoroughly revised his poems after the war. Though some of the poems concerning the experience of occupation have been preserved in the published editions in the 1950s and 196os, their obscurity has only increased after revision. It is thus particularly important to study the versions published during the occupation. For more on this, see Chiu Yi-Hsuan 邱怡瑄, 'Shishi zai xinwo yu guwu zhijian: lun Qu Tui-yuan's Bushutang shilu' 詩史在新我 與故吾之間：論㫿蛻園補書堂詩錄 (The poetised history amid the 'present-self' and the 'previous-self': on Bushutang shilu by Tuei-yuan Qu), Taida zhongwen xuebao 臺大中文學報 (National Taiwan University Chinese Journal) 70 (2020, forthcoming).

8 These chronological accounts of Qu Xuanying are based mainly on Tian Ji 田吉, Qu Xuanying nianpu 篗宣穎年譜 (A Chronology of Qu Xuanying), PhD dissertation (Fudan University, 2012). 
poem ‘On Yishan's “Unofficial History Pavilion”' (Yong Yishan yeshiting 詠遺山 野史亭)..$^{9}$ Judging from its title and content, Qu's poem seems to be about Yuan Haowen 元好問 (sobriquet Yishan 遺山, 119o-1257), a poet who lived between the Jurchen Jin and the Mongol Yuan Dynasties. However, the last two poems included in the eighth volume of Huang's posthumous Poetry in the WindListening Hut (Lingfengyi shi 聆風箖詩) were apparently written in response to Qu's poem. In terms of context and time, Qu's letter-poem must have been composed on the eve of the downfall of Beiping, or when the city was already under siege, and must have been written as a way for him to bid farewell to his friend. It reads:

貞祐南遷知禍始

天興北度賴身留 入燕委屈寧初意

存趙艱難有至謀 肯以文章媚崔立 聊將編簡望張柔 暮雲樓閣知何世

In the Zhenyou era, when the capital was moved southward, he [Yuan Haowen] knew a calamity had begun; ${ }^{10}$ In the Tianxing era he was fetched north and kept alive."1 How could the northward escape be his initial expectation?

His effort to save the fatherland was a long-term plan. ${ }^{12}$ $\mathrm{He}$ was willing to fawn on $\mathrm{Cui}_{\mathrm{Li}}{ }^{13}$ with flattering tributes; He befriended Zhang Rou ${ }^{14}$ to gain access to archives. In the evening cloud-wreathed pavilion, which year is the year?

坐對韓山翠黛愁 Facing the hills of Hanyan, ${ }^{15}$ his brows knitted in sorrow.

9 See Zhonghe 5, 4 (May 1944): 51; and Qu Xuanying, Bushutang shilu: Jia bian 補書堂詩 錄 • 甲編 (Poetry in the Hall of Mending Books, Part 1) (1965 mimeographed copy stored by the Archive of the Chinese University of Hong Kong Library), 3: $10 a$.

10 Zhenyou 貞祐, the first regnal name adopted by Emperor Xuanzong of Jin 金宣宗 (11631224, r. 1213-1224) from 1213 to 1217. In 1214, upon the Mongols' attacks on the Jin, Xuanzong left the original capital of Zhongdu (present-day Beijing) and moved southwards to Bianjing (present-day Kaifeng).

11 Tianxing 天興, a regnal name adopted by Emperor Aizong of Jin 金哀宗 (1198-1234, r. 1224-1234) from 1232 to 1234, right before the Jin Dynasty was conquered by the Mongols. Yuan was recommended to the Mongol court for his literary talents, and thus survived.

12 Lord Xinling 信陵君 (?-243 BC) once helped his brother-in-law, Lord Pingyuan 平原君 $(?-251 \mathrm{BC})$, to save the besieged city of Handan, the capital of Zhao, from the Qin army.

13 Cui Li 崔立 (?-1233) was a Jin general who surrendered to the Mongol army. Later, Cui asked Yuan and other literati to write tributes, praising him for saving many lives in Bianjing. Yuan at first refused to this, but eventually agreed.

14 Zhang Rou 張柔 (1190-1268), a general, possessed the lost Jin Shilu 金實錄 (Veritable Records of the Jin), which was essential for Yuan Haowen to compile a history of the Jin.

15 Yuan Haowen was born and buried in Hanyan (now Xinzhou, Shanxi Province). 
On the surface, this octave is a poem about history, a subgenre in Chinese classical poetry. Following this tradition, every single word in Qu's poem has to be closely linked to the life of the historical figure Yuan Haowen. However, the perspective that $\mathrm{Qu}$ adopts for depicting Yuan's life in this poem actually includes Qu's own evaluative and annotative remarks about Yuan. During armed conflicts at the end of the Jin Dynasty, Yuan wrote letters to enemy generals in order to seek a chance to survive. He then befriended Jin renegades, hoping that by doing so he might glimpse some of the historical literature of the Jin Dynasty that had been scattered during the conflict. All these acts constituted 'fraternising with the enemy', and may have been regarded as morally controversial and disgraceful misdeeds. However, arguing that 'his effort to save the fatherland was a long-term plan', Qu defended Yuan's behaviour by arguing that these were expedient means with a noble goal—namely, to preserve the history of the Jin Dynasty. In Yuan's case, Qu believed that there might well be more possible motives behind the literati's apparent efforts to seek survival, motives that included preserving the history and memories of a fallen state.

Why did Qu Xuanying choose to praise a poet-historian who had lived in occupied lands when writing a farewell letter to his lifelong friend? The response poem by Huang Jun provides some clues for decoding the poem. In 1937, Huang was a secretary in the Executive Yuan of the Nationalist Government in Nanjing under Chiang Kai-shek 蔣介石 (1887-1975). He was also known as a columnist of literary and historical essays, as well as a talented classical poet. In late August 1937, not long after receiving Qu's poem, Huang, together with his eldest son Huang Sheng 黃晟 (1911-1937), became the first Chinese to be accused of being Hanjian 漢奸 ('traitors to the Han nation') through their alleged espionage for Japan. They were executed by firing squad on 26 August 1937. Huang's collaboration shocked literati circles, foreshadowing the prospect that all literati might have to pay a hefty price if they were suspected of having 'fraternised with the enemy'. Huang thus must have replied to Qu's poem during the siege of Beiping that lasted from July to August, 1937.

The last two poems that Huang composed before his execution were both written to $\mathrm{Qu}$. The first poem reads: ${ }^{16}$

夷狄固無厭 The aggressors are undoubtedly insatiable;

駔儈豈能國 But how can those crude compradors rule a state?

輕心重自侈 Being indiscreet and ostentatious,

16 Huang Jun, Lingfengyi shi 聆風簃詩 (Poetry in the Wind-Listening Hut) (Taichung: Gaowen chubanshe, 2017; copied edition of the 1941 print edition), 8: $36 \mathrm{~b}$. 
召侮迺此極 Extreme insults are expected to be incurred.

與君撫銅駝 The bronze camel [by the palace gate] that we once caressed,

早料在荊棘 Was buried again in the thorns as expected. ${ }^{17}$

蒼天復黃天 A yellow sky replaced the blue sky; ${ }^{18}$

二夕坼其北 North China collapsed in just two days.

媄君困玉貌 I sigh about your [noble,] jade-like countenance;

安得傅羽翼 Could you grow wings to escape [the besieged city]?

修羅初雨兵 With armies as fierce as Asura, a rain poured down to cleanse the weapons; ${ }^{19}$

及終有難測 And no one can predict the end of this battle.

萬方必熛怒 Raging flames of war are overspreading everywhere,

將以蕩昏黑 Which shall convulse even the darkest corners of the world.

瓦注誰寸全 Trivial stakes like ceramic pots will not survive intact;

慘滄入新域 And I dismally arrive in this new land.

正虞文字燼 Worrying that my words shall all turn to dust,

何止煙竾逼 What's more, there are now approaching flames of battle.

君勤徵文獻 You are diligent in collecting historical documents,

我亦好浪墨 And I enjoy wasting my ink [on writing] too.

舊京真可念 How much on my mind is the ancient capital Beiping!

下筆意千織 I cannot help but have mixed feelings while writing [this poem].

南遷判祜始 The hasty relocation of the capital southward initiated all these troubles,

北顧幾慚色 Looking north now, who wears a look of shame?

他年傳薟言 If someone passes to you these words in the future,

追想共悽惻 It must be sad recalling [the past] just as the present-day 'me' does.

Huang had a habit of discussing current affairs and political issues through poetry. He also often employed the writing technique of 'infusing historical events and comparing them with facts from the past'. ${ }^{20}$ For example, the fifth

17 These two lines allude to the Chinese idiom tongtuo jingji 銅駝荆棘 (bronze camel in thorns), symbolising a shattered scene after a homeland has been ruined. See Fang Xuanling 房玄齡 et al., 'Suo Jing zhuan' 索靖傳 (Biography of Suo Jing), Jin shu 晉書 (History of Jin) (Beijing: Zhonghua shuju, 1974), vol. 6, 6o: 1648 .

18 A late Han Dynasty children's ditty ran: 'The blue sky is dead; a yellow sky will be established.' This was taken to be a prophesy foretelling the end of the Han reign.

19 Asura was a class of demon in Hindu mythology. Allegedly, before King Wu of Zhou's 周武 王 final battle to overthrow the Shang Dynasty, it rained. This was taken as an auspicious sign, since Heaven was helping to cleanse his weapons.

20 Liang Hongzhi 梁鴻志, 'Preface', in Huang Jun, Lingfengyi shi. 
couplet, 'I sigh about your [noble,] jade-like countenance,/ Could you grow wings to escape [the besieged city]?', contains the key imagery in the poem in response to Qu Xuanying's situation. In this couplet, Huang alludes to the famous strategist Lu Zhonglian 魯仲連 (c. $305^{-245}$ BC) during the Warring States period $\left(475^{-221} \mathrm{BC}\right)$. The narrative also happens to be a historical story in the context of a 'besieged city'. In The Strategies of the Warring States (Zhanguo $c e$ 戰國策), Lu Zhonglian, representing the state of Zhao (besieged by the Qin army), met Xinyuan Yan 辛垣衍, a general from the state of Wei, trying to convince the King of Zhao to support the King of Qin in becoming emperor. Lu Zhonglian at first did not speak. Xinyuan surmised from his '[lofty,] jade-like countenance' that he was not a man craving the favour of Zhao; so why did he stay during the siege and refuse to leave ${ }^{21} \mathrm{Lu}$ then convinced Xinyuan that Wei's friendship with Qin, a hegemonic power, was fundamentally flawed, as 'the righteous would not make Qin the emperor' ( $y i$ bu di qin 義不帝秦). Huang Jun thus compares Qu Xuanying to Lu Zhonglian, both being figures who had chosen to stay in a besieged city. When alluding to this narrative, Huang adopted the method of 'quoting out of context' (duanzhang quyi 斷章取 義): that is, using only a partial meaning of the allusion. What he thus emphasises is the helplessness and sense of urgency of being trapped in a besieged city, while also hinting at possible stratagems hidden in Qu's mind.

We do not know exactly when Qu Xuanying read this response poem by Huang Jun. On the other hand, Huang's last poem, entitled 'Rainy Night' (Yu $x i$ 雨夕), was obviously also written to lament Qu's situation in Beiping. The first four lines of the poem read: ${ }^{2}$

舊京北隔陣雲深 From the former capital in the north hidden in clouds of gloom,

有弟音書黯黯沉 News of my brother makes me feel heavy and dark.

自調久知成此日 Self-deceit aside, I had long known that this day would come;

偕亡終嘆負初心 But falling together with the state was not our original plan.

In the previous poem, Huang Jun was more resentful and critical; this quatrain, however, fully reveals the deep melancholy that he felt upon receiving Qu's letter. These poems show the lasting suffering and uncertainty brought about by

21 See 'Qin wei Zhao zhi Handan' 秦圍趙之邯鄲 (Qin besieging the Handan city of Zhao), in Zhanguo ce zhushi 戰國策注釋 (The Commentated Edition of Strategies of the Warring States), ed. He Jianzhang 何建章, vol. 2 (Beijing: Zhonghua shuju, 1990), 736. 
the situation of occupation. They combine the poet's sorrow for the destruction of his homeland with his confusion over the sudden loss of his existing career. Enemy occupation is often regarded as a sudden turning point in history but, for people experiencing such a situation, this transition has an unpredictable outcome and involves a significant gamble of life or fortune. In such high-risk circumstances, people have to make crucial decisions about whether to leave or to stay, to endure or to resist. This unusual circumstance is important for understanding the literati's state of mind, and their literature, in this period.

The prospect of the fall of China exerted a high psychological pressure on individuals living in such epic times. The spectre of regime change was unmentionable, because it would be considered defeatism when united resistance was demanded of all Chinese. This situation thus compelled poets to find historical parallels and employ subtle expressions in their poetry. Yuan Haowen, a 'literary precursor', had inspired Qu Xuanying in a vulnerable situation, enabling him to come up with ways of survival in such a hard time. However, the moral suspicion of accommodation and collaboration left him with no other choice but to disguise his claims as comments on historical events when sending messages to friends. Chinese poetry has its tradition of esoteric writing. While interpreting these poems, we should be aware of their hidden intentions.

\section{3}

\section{Qu Xuanying and His 'Unofficial Historian's Pavilion'}

As discussed above, Qu Xuanying used a poem on Yuan Haowen as a farewell letter to express his emotions. Qu recognised himself as somehow being in the same situation that Yuan had been in following the collapse of the state. Qu came to realise that the safety of his life, family and assets required submissiveness and patience. Thus, through the historical positioning that Yuan had adopted, Qu found significance for the second half of his own life. It is worth noting that Qu did not hold his positions in north China for very long under occupation, but he attached great importance to his work as editor-in-chief of a monthly periodical called Concordia - a magazine that was published in the occupied areas for a number of years through Qu's perseverance, and that focused on literature and history. Qu's 'Foreword' to the journal declared his 'feeling the importance of understanding the present by learning from the past'. This statement demonstrates why Qu sent Huang Jun his poem on Yuan Haowen, for he trusted that Huang would understand the similarities between his own predicament and those that had once been faced by Yuan Haowen, as well as the choices he was making. 
Yuan Haowen's enthusiasm for and dedication to the preservation of historical documents had been enough to drive him to 'fraternise with the enemy'. The same belief in the preservation of culture was perhaps what prompted Huang Jun to write, in his response poem to Qu: 'Worrying that my words shall all turn to dust, / what's more, there are now approaching flames of battle. You are diligent in collecting historical documents,/ and I enjoy wasting my ink [on writing] too.' While Qu thought of Yuan at a critical juncture, Huang also kept in mind their shared passion for literature. For these two literati, the condition of living in a 'besieged city' not only symbolised a loss of life and a lack of freedom of movement, but also the anxiety over the longevity of their careers as men of letters. Qu seemed to see himself through the historical figure Yuan Haowen, valuing the compilation of history over the preservation of his own reputation. As Qu declared in the foreword of the monthly Concordia:

This magazine does not dare to make any arbitrary claims. Instead, it serves to provide various researchable documents, in a calm manner, for readers' selection and perusal. We feel the importance of understanding the present by learning from the past, so we intend to focus as much as possible on the introduction of historical materials. ${ }^{23}$

This paragraph avoids a declaration of any political stance, and instead defines the monthly as 'a magazine for collecting historical sources'. Owing to the involvement of Japanese funding and influence in Concordia, however, it was difficult for the magazine to rid itself of the Hanjian label. ${ }^{24}$ Although Concordia did contain some pieces expressing an opinion on the promotion of Sino-Japanese friendship and discussing the history of exchanges between the

23 Zhonghe 1, 1 (1940): 1-3.

24 For scholars who maintain that Concordia was a journal of cultural propaganda on Japan's behalf, see Song Yongsheng 宋永生, 'Sixiangzhan' zhi qianyan zhendi: Zhonghe yuekan yanjiu「思想戰」之前沿陣地：《中和》月刊研究 (The Frontier of a War in Thoughts: A Study of Concordia Monthly) MA thesis (Central China Normal University, 2012). Other scholars argue that, even if this was the case, the academic value of this journal should not be ignored. See, for example, Yu Jing 于靜, 'Lin Chen cang lunxianqu qikan: Zhonghe yuekan' 林辰藏淪陷區期刊 : 《中和》月刊 (The journal Concordia published under the occupation in Lin Chen's collection), Lu Xun yanjiu yuekan 魯迅研究月刊 (Lu Xun Research Monthly) 5 (2007): 70-75; Sang Bing 桑兵, 'Zhonghe yuekan jieshuo' 《中和》 月刊解說 (An analysis of Concordia monthly), in Jiaoliu yu duikang:Jindai Zhong-Ri guanxi shilun 交流與對抗：近代中日關係史論 (Exchanges and Antagonism: A History of Sino-Japanese Relations in the Modern Era), ed. Sang Bing (Guilin: Guangxi shifan daxue chubanshe, 2015). 
two countries, most of the magazine's contents were literary and historical in nature, and most were selected to introduce the circumstances, culture and events of the past. Like Yuan Haowen, Qu Xuanying paid great attention to the historiography of his fallen homeland. His concerns about China and the world were based on the idea of 'understanding the present by learning from the past'. As Qu remarks about Yuan Haowen: 'His effort to save the fatherland was a longterm plan.' Qu probably also compared his own choice to Yuan's. Even though both Yuan and Qu could not escape allegations of having collaborated with the enemy (in their respective eras) based on speculation over their personal motives, Yuan's Anthology of the Central Plain (Zhongzhou ji 中州集), just like Qu's extensive collection of literary and historical materials published in Concordia, was indeed a form of 'national salvation' during the occupation period. Furthermore, were the literary works published in Concordia all 'pro-Japanese'? In the poems that Qu wrote under occupation, we can actually find contents that defy such claims.

Qu Xuanying's writing is simultaneously commentary on Yuan Haowen's survival. While a man could do little to turn the tide of the time, Qu Xuanying and Yuan Haowen both chose to live, in order to save the possibility of 'composing history' for the future, their future selves included. Their choice thus cannot be reduced to the polarity between collaboration and resistance, but in effect transcended this binary by adopting the perspective of the future. Their determined survival was for a higher purpose than saving their own lives: it was to preserve historical memories. This 'third path' taken by literati under the occupation was a moral option that the current field of research has so far neglected.

\section{'The Congealed Jade Pool'}

In a 1944 issue of Concordia monthly, Qu Xuanying published the following two poems under one title: 'On "The Congealed Jade Pool", written in the rhyme han and "During a Poetry Society Gathering"'.25 The 'poetry society gathering' here refers to the occasion when the poems were composed-that is, the collective exchange among a group of poets. These poems were probably composed between the end of July and mid-September 1937. They refer to a poem commonly referred to as 'The Congealed Jade Pool' (Ningbi chi 凝 碧池) by Wang Wei 王維 (699-761), a Tang poet who had experienced the An

25 Qu Xuanying, 'Sheji yong Ningbi chi shi de Han yun' 社集詠凝碧池事得寒韻, in Bushutang shilu:Jia bian, 3: 10a-b. First published in Zhonghe 5, 4 (1944): 51. 
Lushan Rebellion $\left(755^{-763)}\right.$ staged by his namesake, a military leader of Sogdian and Göktürk origin.

The first poem reads:

宮槐槭槭暮生寒 The palace sophoras shed their leaves and emitted chills at dusk;

四座同驚義士肝 All present were amazed at the fearless courage of the martyrs.

砑帽山香空自舞 Wearing flower-adorned hats, dancers move to the melody of 'Fragrant Mountain',

霓裳水殿若為歡 'Rainbow robes' in the palace of flowing water re-enacts the imperial nuptial joy.

緣雲清切移情易 Crystal-clear songs climbing the clouds easily move emotions;

捧日忠誠事敵難 Hard to serve an enemy with the loyalty of 'holding the sun'. 說與㖣州應有恨 If this sentiment is shared in Kuizhou, one should feel regret!

法歌變轉涕汎瀾 Tears stream down on the shifting notes of the dharma song.

The first line appropriates imagery from the first two lines of Wang Wei's original poem: 'Leaves of the autumn sophoras fall within the empty palace;/ While at the Congealed Jade Pool they have pipes and strings performing, ${ }^{26}$ which describe the view in an uninhabited palace. Wang's lines depict the court musicians who were forced to convene and play the music of the Tang Dynasty for the triumphant rebels. The author empathised with the humiliated musicians who had to 'accommodate' the enemy. The historical allusions and the present circumstances of survival thus produce an effect of inter-reflection between the present and the past, through the analogy of historical context. The 'martyr' refers to the musician Lei Haiqing 雷海清, who threw his instrument to the ground in anger and was immediately dismembered by the rebel army. At that time, Wang Wei had been confined to a monastery on the outskirts, and wrote the poem after hearing about this incident. Ostensibly, Qu's poem is about joyous scenes of a feast, but what is hidden underneath is the typical

26 Wang Wei's original line: 秋槐葉落空宮裏, 凝碧池頭奏管絃; see Wang Wei, 'While I was imprisoned at Bodhisattva Monastery, Pei Di came to see me. He said that the rebels had music performed at the Congealed Jade Pool. The court musicians ceased their playing and all shed tears at once. I then improvised this verse privately and chanted it to Pei Di' (14.26), in The Poetry and Prose of Wang Wei, trans. Paul Rouzer (Berlin: De Gruyter, 2020), vol. 2, 157 . 
style of 'illustrating sadness through cheerful scenes' - the more magnificent the musical performances, as they were during the heyday of the dynasty, the more ironic the present situation became.

Most allusions in the poem above refer to the grand literature written in the prosperous Kaiyuan and Tianbao periods. The phrase 'flower-adorned hats', for example, alludes to Li Jin 李﨎 (?-750), the Prince of Ruyang, who:

often wore a smooth silk hat and danced to music. Once Emperor Xuanzong picked a red hibiscus flower and inserted it onto the brim of Li Jin's hat ... The musicians then performed the song called 'Dancing in a Fragrant Mountain' (Wu shanxiang 舞山香), and Li Jin danced to it. ${ }^{27}$

The reference to "Rainbow robes" in the palace of flowing water' alludes to the story of Emperor Xuanzong of Tang 唐玄宗 $\left(685^{-762}\right.$; r. 712-756) and his consort Yang Yuhuan 楊玉環 (719-756), taking a nap together in the day in a palace surrounded by flowing streams. 'Rainbow robes' was a piece of music that the emperor created and to which the imperial consort danced. These were some of the most gorgeous scenes of the Tang Dynasty during the Kaiyuan era.

The most striking lines in Qu Xuanying's poem, however, lie in the third couplet. The line 'crystal-clear songs climbing the clouds' is appropriated from Du Fu's (712-770) poem entitled 'Song of Leyou Park' (Leyouyuan ge 樂遊原歌), ${ }^{28}$ written before the An Lushan Rebellion. At that time, Leyou Park was a place where the imperial nobility banqueted and spent their leisure time. Although Du was also present at a banquet, watching musical and dancing performances, it was hard for him to enjoy them. Therefore, despite the beauty of the singing, he wrote: 'I recall the times when I was drunk year by year,/ but now I am saddened before intoxicated.' The poem ends with an image of Du standing alone, with nowhere to go. The poet displays complex feelings of alienation despite the pleasures of the moment. Qu appropriates this phrase to borrow Du's sense of alienation and awkwardness so as to lament the changes that he witnessed in his time. 'Holding the sun' refers to a narrative from the History of the Wei. ${ }^{29}$ In the middle of the night, a Wei general once dreamed of 'climbing Mount

27 Nan Zhuo, 南卓 Jiegu lu 羯鼓錄 (On the History of the Double-Headed Drum) (Beijing: Zhonghua shuju, 1985; Congshu jicheng edition), 6-7.

28 Du Fu, 'Leyou yuan ge' (Song of Leyou Park), in Dushi xiangzhu 杜詩詳註 (A Detailed Annotated Edition of Du Fu's Poetry), ed. Qiu Zhao'ao 仇兆鰲 (Beijing: Zhonghua shuju, 2015), 2: 89-9o.

29 This story, originally appearing in Weishu 魏書 (History of the Wei), was quoted by Pei Songzhi 裴松之 in his annotation of Sanguozhi 三國志 (History of the Three Kingdoms); see Sanguozhi (Beijing: Zhonghua shuju, 1982), 14: 427. 
Tai with the sun held in his hands'. Legend has it that, after hearing about this dream, Cao Cao 曹操 $\left(155^{-220}\right)$ superimposed the glyph of the character $r i$ 日 (lit., sun) on to that of the character $l i$ 立 in Cheng's original name 'Cheng $\mathrm{Li}$ 程立'一which was then changed to Cheng $\mathrm{Yu}$ 程昱 (?-220)—in order to commemorate his dream of holding the sun. This phrase can therefore refer to the caution that one feels when serving the emperor, as being in the company of absolute power is as terrifying as holding the sun. Combining these historical allusions, Qu's entire poem can be interpreted as suggesting that it is easy to reproduce the banquets, music and graceful dance of a previous dynasty, but serving an emperor (let alone a new conqueror) is as difficult as holding the sun.

However, the phrase 'holding the sun' had an even more intriguing interpretation in the context of the Japanese occupation. The sun was, of course, a symbol of the Japanese national flag. Qu's use of this phrase, then, can help shed light on why Qu published poems with similar lines in the monthly Concordia, a publication that was accused of being pro-Japanese. In particular, by reverse-deducing the circumstances of enemy occupation at the time when he was writing poetry, it is noticeable that these poetic themes and emotions all touched on issues that were politically taboo. Such 'esoteric resistance' would actually have been difficult to write had it not been for the historical distance enclosed in the historical allusions used in Qu's works. However, writers and readers of classical-style poetry living at Qu's time shared a certain interpretive system, in which ancient and modern events were deemed analogous to each other. Using this system, Qu could thus hide tacit understandings of his true intent in hidden historical allusions.

The last two lines of Qu Xuanying's poem include another similar scene in which the music of a preceding dynasty was heard. Du Fu, who had followed the imperial Tang court into exile during the An Lushan Rebellion, spent his later years in Kuizhou, a remote region in western Sichuan, where Du also had the experience of listening to Tang court music. In one poem, ${ }^{30} \mathrm{Du}$ describes a banquet where he incidentally heard the performers of the Pear Garden (Liyuan 梨園) Troupe playing a piece of music that had been personally performed by Emperor Xuanzong during the Kaiyuan era. The melody moved all the guests to tears in reminiscence of the formerly prosperous Kaiyuan times. For Du in exile, this was not just a nostalgic lament for a past golden age; it was

$30 \quad$ See Du Fu, 'Qiuri Kuifu yonghuai fengji Zheng jian (Shen) Li binke (Zhifang) yibai yun' 秋日熟府詠懷奉寄鄭監審李賓客之芳一百韻 (On an autumn day I express my thoughts in the Kuizhou magistrate's mansion, thinking of Zheng Shen and Li Zhifang, and write a poem of a hundred rhymes), in Dushixiangzhu 19: 1402-1415. 
also linked to his endless nostalgia for his home town of Chang'an. Moreover, in his poem, Du wrote that he sincerely hoped that 'the waters of the Dragon Stable' (Longjiu zhi shui 龍廐之水) flowing through the moat around Chang'an would never again be contaminated by the stench of the foreigners' steeds. Here, readers who were familiar with the metaphorical devices of classical Chinese poetry would have been able to grasp some of the underlying meanings. Qu Xuanying borrowed this implication from Du's poem and therefore secretly hid in his own poem sentiments that he could not have openly expressed. For the literati who stayed in the Japanese-occupied areas of north China, the line 'Hard to serve an enemy with the loyalty of "holding the sun"' not only evokes cultural and historical memories, but also reflects the situation that they were experiencing.

\section{The Hu and the Han: Esoteric Writing under the Occupation}

Qu Xuanying's second poem on 'The Congealed Jade Pool' also skilfully employed the technique of alluding to his current feelings through meditations on the past. This poem read:

漁陽突騎滿長安 The Yuyang Cavalry suddenly permeated all over Chang'an; 今日威儀想漢官 Their majestic presence reminds me of that of the Han court.

鳳尾檀槽甘併碎 Phoenix-tailed or sandalwood-stringed: precious instruments become broken fragments;

龍池柳色忍重看 I hardly bear to revisit the willows by the Dragon Pool.

哀絃暗入聲聲淚 Sorrowful strings quietly mingle with tears note by note;

腐草長露寸寸丹 Decayed plants forever stained with vermilion inch by inch.

卻笑琵琶作胡語 Instead of laughing at the pipa lute speaking a Turkic tongue,

何如生世值高歡 How about seeing the Gao Huan era during our lifetime?

The first couplet describes the sudden occupation of the capital by the 'Yuyang Cavalry' - the rebel army led by An Lushan. Their impressive military presence had made the author recall a scene in which hundreds of officials gathered in the city of Chang'an during the golden age of Tang. This allusion also refers to the line 'When will the hundreds of officials ever attend morning court sessions again' in Wang Wei's poem 'The Congealed Jade Pool'. When new troops arrived in Beiping, a 'former capital' with many memories of imperial glories and downfalls, was it the disappearance or the return of historical glory? The 
second couplet then employs the allusion of an elegiac poem entitled 'Written on the Back of a Pipa Lute' by Li Yu 李煜 (c. 937-978, r. 961-976), the last ruler of the Southern Tang. This poem was inscribed on the back of the pipa left by his deceased queen, and its last couplet reads: 'In the phoenix tail-shaped neck [of the pipa] your heavenly fragrance lingers, and your remaining warmth stays in [its] sandalwood string-bridge. ${ }^{31}$ This historical allusion is applied in the form of antiphrasis in Qu Xuanying's poem, which is also related to the aforementioned allusion of the musician Lei Haiqing's martyrdom after breaking his instrument. It thus implies that the performer and the instrument perish together. But in the third couplet, the main theme that illustrates the court music of the golden age is shifted to a low-spirited, melancholic tune. This description alludes to the fact that everyone was heartbroken upon learning that the musician had sacrificed his life for this righteous act. As for the fourth and last couplet, Qu appropriated a line by Du Fu in 'The Five Poems Expressing My Feelings on Ancient Traces', in which Du alluded to Wang Zhaojun 王昭 君, the famous palace beauty whose marriage to the King of Xiongnu brought peace between the Han Dynasty and its nomadic neighbours (believed to be a Turkic people), in the line 'For a thousand years the pipa speaks the Turkic tongue. ${ }^{32}$ Originating in Turkic culture, the pipa had instead turned into Wang's reliance in expressing homesickness while leaving the Han to enter Xiongnu territory. The last line refers to the Northern Qi emperor Gao Huan 高歡 (496-547), a Han Chinese who was greatly influenced by the nomadic Xianbei culture. As his entire family had lived in the north for generations, Gao adopted Xianbei habits and culture.

This couplet thus reflects the perpetual confrontation between the 'foreign' and Chinese regimes. In fact, whether it be the An Lushan Rebellion as experienced by Wang Wei, the transitions between the Jurchen Jin and the Mongol Yuan Dynasties as encountered by Yuan Haowen, or the situation that north China experienced when it fell to Japanese forces in 1937, a cultural anxiety about 'the downfall of China proper' lies behind all of these. Moreover, it is striking that the Jin Dynasty to which Yuan pledged loyalty was also once regarded as 'foreign' by the Southern Song. However, both the Jin and the Southern Song would consider their later conquerors- the Mongols— - to be 'barbar-

31 Li Yu's original line: 天香留鳳尾, 餘暖在檀槽; see 'Shu pipa bei' 書琵琶背 (Written on the back of a pipa lute), quoted by Ma Ling 馬令, Nantangshu 南唐書 (History of the Southern Tang), in Congshujicheng chubian 叢書集成初編 (First Compilation in the Series) (Beijing: Zhonghua shuju, 1985; Congshu jicheng edition), 3851, 6: 8a.

32 Du Fu, 'Yonghuai guji wu shou' 詠懷古跡五首 (Five poems on ancient sites), in Dushi xiangzhu, 17: 1240-1242. 
ians. Thus, the cause of misery in these cases of invasion and occupation also included anxieties caused by the fall of a capital city conquered by a foreign ethnic group.

Notably, in his poem, Qu Xuanying re-examines and reinterprets the significance of the 'Congealed Jade Pool' story through the nationalist conflict between Chinese and 'foreigners'. The courageous musician Lei Haiqing was admittedly admirable for his righteous resistance against the enemy, but at the same time, through posing a rhetorical question in the last line of the poem'How about seeing the Gao Huan era during our lifetime?'-Qu also offered space for readers to reflect on whether 'barbarians' and 'Chinese' really held absolutely incompatible value systems. 'The pipa lute speaking a Turkic tongue' brings to light an interesting albeit paradoxical cultural image. Many Chinese musical instruments, including the pipa, as well as the palace music of the Tang court, actually originated from what are now the western regions of China in the medieval period. Thus, when one plays the pipa in nostalgia for the Central Plain, what does this music actually mean? Is it a feeling rooted in returning to or leaving the homeland? Here, the very question 'How about seeing the Gao Huan era during our lifetime?' challenges the deep-rooted distinction between 'Chinese' and 'barbarians'. Will there really be less pain and sacrifice, provided that we can accept foreign cultures just as Gao Huan did? Without doubt, Qu was skilled at composing poems with historical stories as backgrounds. But in these poems, he did not merely replicate the existing logical implications of the historical allusions. In his works about 'The Congealed Jade Pool', Qu certainly adopted the inherent painful themes in relation to the dramatic circumstances of a country that had fallen into the hands of foreign invaders. However, he also secretly added personal historical interpretations within his poems. Perhaps not everyone shared a belief in an unquestionable and mono-ethnic sense of national identity.

Qu Xuanying's Unique Historical Viewpoints on Beiping

Nicholas L. Chan has studied Qu Xuanying's Poetry Notes on Looking into the Past in Beiping (Yandu langu shihua 燕都覽古詩話), a collection of poetry and notes that were also serialised in Qu's Concordia magazine. ${ }^{33}$ A thematised

33 Chen Weishun (Nicholas L. Chan), ‘Changjiao kuimai qi chunfeng’ 長教葵麥泣春風 (Long letting the sunflowers and barleys cry in the spring breeze), Xinwenxue pinglun (New Literature Review) 新文學評論 4 (2018): 154-168. 
introduction to the history of Beiping as a capital city, this book narrates a number of different historical stories about the city, each of them accompanied by a poem, together with essays explaining the corresponding poem and its historical account. As Chan observes, Qu often conveyed in his works the historiographical judgement of 'accepting the Liao, Jin, and Yuan dynasties as orthodoxy' and 'not regarding An Lushan as a rebel'. In other words, Qu, a scholar of literature and history, realised that the history of Beiping was actually a history of ethnic integration. The city's diverse and rich history was interwoven by the coming and going of rulers who could claim very different origins and consanguinities. Therefore, these 'foreigners' were not necessarily the absolute 'others'. Indeed, Qu's thoughts on the relationship between the $\mathrm{Hu}$ (a generic term for northern nomads) and the Han no longer reflected the pure ethnocentrism of the Han. Instead, Qu often presented insightful and distinctively historiographical arguments in his poems. These viewpoints, which do not take 'the Han nationality' to represent the supreme centre of the world, also created more space for humanistic reflections on the original moral that 'the righteous would not serve a Hu barbarian' ( yi bu shi hu 義不事胡) in the 'Congealed Jade Pool' story.

However, the two 'On "The Congealed Jade Pool"' poems were not fully preserved by Qu when he compiled the final version of his collection of poetry in the 196os, as Qu deleted the first poem, leaving only the second (with revisions). The background of this composition (i.e. 'poetry society gathering') was also removed from the title. Significant changes can be seen among the lines too. For example, the first couplet was modified from:

漁陽突騎滿長安 The Yuyang Cavalry suddenly permeated all over Chang'an; 今日威儀想漢官 Their majestic presence reminds me of that of the Han court.

to:

參軍蒼鵠沐猴冠 The staff officer and the grey hawk were hatted monkeys; 司隸猶云想漢官 But the Metropolitan Commandant was still reminiscent of the Han court.

The original couplet describes the militarised nature of the city under foreign occupation, reminding viewers of the heyday of the former Chang'an. The revised version instead alludes to the Tang comedy of a staff officer and a grey hawk cross-questioning each other; this is a metaphor for the complete reversal of the upper and lower ranks when north China was under Japanese occupa- 
tion. Officers of the occupying army were likened to 'bathed monkeys wearing hats' (muhou er guan 沐猴而冠), whose appearance was little more than a costume; only their subordinates praised them as possessing the same gravitas as the former Han court. After amending the lines here, Qu's stance also seemed to have completely reversed, having been transformed from admiration for a powerful foreign military presence into mockery of that same foreign army as 'bathed and hatted monkeys'. That said, without any personal testimony from the author himself it is difficult to determine the real reasons as to why these poems were modified. By replacing 'the Yuyang Cavalry' with 'the staff officer and the grey hawk', Qu abandoned the views on ethnic equality that he had championed under the Japanese occupation, and returned to a conventional discourse of belittling 'foreigners' as nothing but contemptible and bestial clowns.

As shown above, the revision of poetic works actually demonstrates the cognitive disorientation and dilemma challenging people under occupation. An inevitable difficulty was being forced to bow to their erstwhile enemy and present-day overlords. Even after the war ended and the situation was reversed, however, the surrender and 'non-resistance' that some had apparently displayed at the start of the war would become new 'crimes' that would inescapably follow them for the rest of their lives. In fact, the scene invoked by the line 'The Yuyang Cavalry suddenly permeated all over Chang'an', as Qu illustrated, is similar to Tai Jingnong's 臺靜農 (1902-1990) descriptions of his shock upon witnessing Japanese troops entering Beiping — as something he recorded in his essay 'My first experience of loss and disorder'. ${ }^{34}$ When the Japanese army suddenly surrounded the city, those who were trapped within it were confronted with an intense threat to life and property. Had such people possessed the hindsight of history, perhaps they could have made a choice between active resistance or passive accommodation. However, as victims in the 'besieged city' who lived in uncertainty and possessed no clear information of events in the outside world at the time, were they really 'betraying their own souls' by deciding to take a different course of action from consequent historical developments?

34 Tai Jingnong, 'Shijing sangluan' 始經喪亂 (My first experience of loss and disorder), in Longpo zawen 龍坡雜文 (Essays of the Dragon Slope) (Taipei: Hongfan shudian, 1988), 141-148. 


\section{Masked Memories: The Significance of Reading 'Literature under Occupation'}

In history, the 'occupation period' itself resembles a 'besieged city'-a historical space-time cocoon from which entrapped people are unable to escape, and within which they are forced to make a choice between life and reputation in the face of an uncertain future. Both Yuan Haowen and Qu Xuanying were trying to determine which step to take next, assuming that they did not have much room for resistance and that the country did not seem to have much chance at the time of being liberated. Even the way in which people such as Wang Wei chose to display their loyalty was in fact quite passive, since they had to struggle for survival under enemy control — unlike the musician who had smashed his instrument and consciously chosen self-sacrifice as a way of making a political pledge of loyalty to a vanquished regime.

This uncertain limbo is an often neglected element when discussing literature in the occupied areas. When studying these works, readers-armed with hindsight - often attempt to determine how writings reflect a sense of humiliation or subordination that is experienced once occupation becomes a reality. But what makes Qu Xuanying's case unique is that he did actually express uncertain feelings in his works. From the letter-poem he sent to his friend Huang Jun on the eve of Beiping's downfall, we can see that he had already 'learned from history by taking it as a mirror' and had had a premonition that he himself would face moral accusations and the ethical dilemma of living under a 'new dynasty' on 'enemy soil' as Yuan Haowen once did. In fact, Qu showed more empathy towards these disgraced historical figures.

If we compare Qu Xuanying's works written during the occupation with revised versions of these same works that were published after the war, we can observe that the true mood of a writer under occupation can deviate from the nationalist position of absolute non-compatibility between the occupant and the occupied. Such a comparison also enables us to see more clearly that, in an ambiguous liminal state such as foreign occupation, any expression of one's stance-be it spoken or written-is highly risky. Whether they were choosing active or passive resistance, the literati were in fact writing under a significant amount of pressure to make a public gesture and take a stance, while at the same time enduring a crisis of survival. In comparison to retrospective labels such as 'traitors' or 'resistance writers', the hesitant gestures displayed in literary works written under siege were, in effect, more typical of literature written under occupation: rather than martyrdom, most people chose simply to wait.

Currently, many researchers compare the literature written in Japaneseoccupied north China with the regional literatures with the distinctive char- 
acteristics of 'colonial literature' that were produced in Manchukuo, Taiwan or Korea under Japanese rule. However, if we undertake a more in-depth discussion of the cultural identity of the literati in occupied north China, Qu Xuanying's case actually reflects that this cultural identity cannot be simply subsumed into a dualistic 'coloniser versus colonised' framework. Qu, who stayed in occupied Beiping, certainly felt as if he were 'falling into the hands of the enemy' when 'the Yuyang Cavalry suddenly permeated all over Chang'an', and when the Japanese asserted control over cultural, political and military affairs in north China. However, as Nicholas L. Chan points out, Qu's historical viewpoint was not entirely in keeping with the conventional distinction that is often made between 'Chinese' and 'barbarians'. Although the poems that Qu wrote to his friend still reveal the pain and regret that he had to face towards the circumstances of 'national subjugation', his suffering may have had more to do with his grief over the previous regime's incompetence rather than hatred towards the invaders.

To put it another way, 'the fall of a state' (wangguo 亡國) is a subjective feeling, but it is not always bound to a pledge of allegiance to those political forces opposing an occupying regime. Qu Xuanying's poems display a complicated psychological space for historical interpretation. When Qu compared himself with Yuan Haowen by employing historical allusions in his poetry, Qu's stance as a 'loyalist' and his identification with a 'fatherland' seem unrelated to his 'serving the enemy'. Qu could understand Wang Wei's feelings, but not necessarily at the cost of his life, like the musician who destroyed his musical instrument to express his loyalty. The significance of reading literature under occupation does not lie in how politically correct the expressions are. Instead, it lies in the shock, anxiety and fear hidden 'between the lines' that often emerge when common people experience a sudden turning point in history. Moreover, while 'living with the enemy', these authors continued to feel fear, as if they were walking on thin ice. However, they nonetheless tried to transform their inner feelings into a unique kind of linguistic art-esoteric writing — hoping that intelligent readers would understand what lay deep in their hearts.

In August 1945, the Japanese-occupied areas of China were 'liberated' following Japan's unconditional surrender. Qu Xuanying at this time composed a poem which paid tribute to Du Fu's 'The Eight Poems on Autumn Meditations' (Qiu xing ba shou 秋興八首) by using the same poem title. However, 
he no longer praised historical figures, this time writing instead about his post-war thoughts: ${ }^{35}$

幾輩流槎犯斗歸 當年玉貌困重圍

未能絕食爰旌目 Unable to starve myself as Yuan Jingmu did,

且復容身杜德機 I instead found a space to live with blocked vitality.

不早渡江交口謫 Not crossing the river at first, I am now censured by everyone.

猶應報漢此心違 My faith in repaying the Han now looks insincere.

淒涼永訣台州掾 Desolately, I bid farewell to the Taizhou official,

秋色天長木葉飛 In autumn's colours, the sky elongates with tree leaves fluttering.

This poem also deploys many allusions. Most notably, its second line refers to the line 'I sigh about your [noble,] jade-like countenance' in Huang Jun's reply to the letter-poem by Qu from besieged Beiping. Qu sighed with regret that those who had left Beiping were returning, one after another, and those stranded in the siege were now dealing with overwhelming condemnation, which not only included accusations that they had not tried to leave the enemy, but also that they had not proclaimed their stance by going into exile. Therefore, Qu regretted that he no longer had the opportunity to prove his loyalty to the country. After 1945, even though Qu witnessed China's liberation from the Japanese, he would once again experience the humiliation of 'living on in degradation'. This also explains why he juxtaposed the two allusions of Yuan Jingmu and du deji 杜德機 ('lived lifelessly with blocked vitality') in the second couplet of his poem. Yuan Jingmu is a virtuous man who, despite his starvation, refuses to eat a thief's food. ${ }^{36} \mathrm{Du}$ deji originally refers to the seemingly lifeless state that a sage exhibits. ${ }^{37}$ Through this, Qu hints at his plight of living as though he were dead in the occupied areas. Through these allusions, $\mathrm{Qu}$ remorsefully blames himself for not going south in the first place but deciding to stay in Beiping, meaning that no one would believe that he still had

35 Bushutang shilu:Jia bian, 4: 2b-3b.

36 See Lie Yukou 列禦寇, 'Shuo fu' 說符 (Explaining signs), in Liezi 列子 (Master Lie), ed. Zhang Changfa 張長法 (Zhengzhou: Zhongzhou guji chubanshe, 2010), 222.

37 See 'Ying diwang' 應帝王 (The normal course for rulers and kings), in Zhuangzi 莊子 (Master Zhuang), ed. Cao Chuji 曹礎基 (Kaifeng: Henan daxue chubanshe, 2008), 161162. 
'faith in repaying the Han'. This phrase refers to the story of Li Ling 李陵, a Han general who surrendered to Xiongnu after his family was executed for his military defeat; though he still cherished loyalty towards the Han, he was publicly condemned as a traitor. ${ }^{38}$ Taizhou yuan 台州掾 ('the Taizhou official') in the last couplet again alludes to the An Lushan Rebellion. In a poem by $\mathrm{Du} \mathrm{Fu}$, he laments the fate of his old friend Zheng Qian 鄭虔 (691-759); because of Zheng's old age, he could not flee the occupied territory. Thus, after the recovery of the Tang, Zheng was purged politically for 'failing to be loyal' and was banished to the remote Taizhou as a lowly official. ${ }^{39}$

While the public was seized by a passion for purging 'traitors' during the Japanese occupation, Qu knew that he would not have the chance to directly air his grievances, but could only write out his esoteric feelings and memories of the occupation through comparable historical allusions and situations. After the end of the war, there were also no longer any friends who would still care about Qu's safety in the besieged Beiping or bid him farewell.

In 1937, Qu Xuanying sent a letter-poem to his dearest friend from the besieged city of Beiping. But after the war ended in 1945, Qu found himself living under yet another 'siege', such that he had to make every attempt to hide and mend the choices that he had made around 1937, just as he revised the aforementioned poem on 'The Congealed Jade Pool'. Many poems that Qu had chanted and composed with Huang Jun were completely removed from the 1965 edition of his The Poetry Collection of the Book-Replenishing Hall - the final version of his self-compiled poetry collection to be published in his later years. Furthermore, as the events related to labels such as 'traitors' and 'collaboration' were politically sensitive following the war, and might even incur punishments, Qu had to change his sobriquet, using his new sobriquet - Tuiyuan (lit., 'moulting garden')—for the rest of his life, thus exhibiting his determination to reform himself and to shed his disgraceful past. Qu was a 'collaborator' who was tortured by the label of being a 'traitor'. The reason why we are still able to study the traces of Qu's literary exchanges with Huang Jun is the existence of the unabridged edition of his poetry anthology that was published in Concordiathe magazine for which Qu served as editor-in-chief during the occupation. However, after 1965, when Huang's name was completely removed from all collections of Qu's poetry, the only clues to Qu's 'esoteric writings', from which we

38 See Ban Gu 班固, Han shu 漢書 (History of the Han), ed. Yan Shigu 顏師古 (Beijing: Zhonghua shuju, 2002), 54: 2450-2459.

$39 \mathrm{Du}$ Fu, 'Song Zheng shiba Qian bian Taizhou sihu' 送鄭十八虔貶台州司戶 (Sending off Zheng Qian, banished to become a staff official in Taizhou), in Dushixiangzhu 1: 356-357. 
can still catch a glimpse of this poet's hidden thoughts, are the historical allusions that recorded the traces of their literary interaction through poetry.

\section{Acknowledgments}

An earlier version of this paper was first presented at the workshop 'Cultural and Intellectual Histories of Japanese-occupied China', held at Asia House (London) on 16 September 2019. This workshop was organised through the coTcA Project, and was thus supported by the European Research Council (ERC) under the European Union's Horizon 2020 research and innovation programme (Grant no. 682081).

\section{Translated by $\mathrm{Ng}$ Chin-fung}

\section{References}

Asami Yōji, Wenben de mima: Shehui yujing zhong de Songdai wenxue 文本的密碼 : 社會語境中的宋代文學 (Textual Codes: Song Literature in Social Context), trans. Li Gui 李貴, Zhao Ruirui 趙芯芯, et al. (Shanghai: Fudan daxue chubanshe, 2017).

Ban Gu 班固. Han shu 漢書 (History of Han), edited by Yan Shigu 顏師古 (Beijing: Zhonghua shuju, 2002).

Barrett, David. 'Introduction: Occupied China and the limits of accommodation'. In Chinese Collaboration with Japan, 1932-1945: The Limits of Accommodation, edited by David Barrett and Larry N. Shyu (Stanford, CA: Stanford University Press, 2001), 1-17. Brook, Timothy. Collaboration:Japanese Agents and Local Elites in Wartime China (Cambridge, MA: Harvard University Press, 2005).

Brook, Timothy. Tongdi:Erzhan Zhongguo de Riben tewuyu difang jingying 通敵 : 二戰 中國的日本特務與地方菁英 (Colluding with the Enemy:Japanese Agents and Local Elites in China during WwII), trans. Lin Tiangui 林添貴 (Taipei: Yuanliu chuban gongsi, 2015).

Brook, Timothy. Zhixu de lunxian: Kangzhan shiqi de Jiangnan wucheng 秩序與淪陷: 抗戰時期的江南五城 (The Collapse of Order: Five Cities in the Jiangnan Region of China during the War of Resistance), trans. Pan Min 潘敏 (Beijing: Shangwu yinshuguan, 2015).

Chen Weishun (Nicholas L. Chan). 'Changjiao kuimai qi chunfeng' 長教葵麥泣春風 (Long letting the sunflowers and barleys cry in the spring breeze), Xinwenxue pinglun 新文學評論 (New Literature Review) 4 (2018): 154-168.

Chiu Yi-Hsuan 邱怡瑄. 'Shishi zai xinwo yu guwu zhijian: lun Qu Tui-yuan's Bushutang 
shilu' 詩史在新我與故吾之間：論篧蛻園補書堂詩錄 (The poetised history amid the 'present-self' and the 'previous-self': on Bushutang shilu by Tuei-yuan Qu). Taida zhongwen xuebao (National Taiwan University Chinese Journal) 臺大中文學報 70 (2020, forthcoming).

Du Fu. Dushi xiangzhu 杜詩詳註 (A Detailed Annotated Edition of Du Fu's Poetry). Edited by Qiu Zhao'ao 仇兆鰲 (Beijing: Zhonghua shuju, 2015).

Fang Xuanling 房玄齡, et al. Jin shu 晉書 (History of Jin) (Beijing: Zhonghua shuju, 1974).

He Jianzhang 何建章 (ed.). Zhanguo ce zhushi 戰國策注釋 (The Commentated Edition of Strategies of the Warring States) (Beijing: Zhonghua shuju, 199o).

Huang Jun. Lingfengyi shi 聆風箖詩 (Poetry in the Wind-Listening Hut) (Taichung: Gaowen chubanshe, 2017; copied edition of the 1941 print edition).

Huang Kaifa 黃開發.ZhouZuoren de jingshen xiaoxiang 周作人的精神肖像(A Spiritual Portrait of Zhou Zuoren) (Shenyang: Liaoning renmin chubanshe, 2015).

Lie Yukou 列禦寇. 'Shuo fu' 說符 (Explaining signs). In Liezi 列子 (Master Lie). Edited by Zhang Changfa 張長法 (Zhengzhou: Zhongzhou guji chubanshe, 2010).

Meltzer, Arthur M. Philosophy Between the Lines: The Lost History of Esoteric Writing (Chicago: University of Chicago Press, 2014).

Nan Zhuo 南卓, Jiegu lu 羯鼓錄 (On the History of the Double-Headed Drum) (Beijing: Zhonghua shuju, 1985; Congshu jicheng edition).

Qu Xuanying. Bushutang shilu:Jia bian 補書堂詩錄 • 甲編 (Poetry in the Hall of Mending Books, Part 1) (1965 mimeographed copy stored by the Archive of the Chinese University of Hong Kong Library).

Sang Bing 桑兵. 'Zhonghe yuekan jieshuo' 《中和》月刊解說 (An analysis of Concordia monthly), in Jiaoliu yu duikang:Jindai Zhong-Riguanxi shilun 交流與對抗：近 代中日關係史論 (Exchanges and Antagonism: A History of Sino-Japanese Relations in the Modern Era). Edited by Sang Bing (Guilin: Guangxi shifan daxue chubanshe, 2015).

Song Yongsheng 宋永生. 'Sixiangzhan' zhi qianyan zhendi:Zhonghe yuekan yanjiu $\ulcorner$ 思 想戰」之前沿陣地：《中和》月刊研究 (The Frontier of a War in Thoughts: A Study of Concordia Monthly). MA thesis (Central China Normal University, 2012).

Strauss, Leo. Persecution and the Art of Writing (Chicago: University of Chicago Press, 1988).

Tai Jingnong. 'Shijing sangluan' 始經毞亂 (My first experience of loss and disorder). In Longpo zawen 龍坡雜文 (Essays of the Dragon Slope) (Taipei: Hongfan shudian, 1988).

Tian Ji 田吉. Qu Xuanying nianpu 矍宣穎年譜 (A Chronology of Qu Xuanying), PhD dissertation (Fudan University, 2012).

Wang Wei. The Poetry and Prose of Wang Wei. Translated by Paul Rouzer (Berlin: De Gruyter, 2020). 
'Ying diwang' 應帝王 (The normal course for rulers and kings). In Zhuangzi 莊子 (Master Zhuang). Edited by Cao Chuji 曹礎基 (Kaifeng: Henan daxue chubanshe, 2008). Yu Jing 于靜, ‘Lin Chen cang lunxianqu qikan: Zhonghe yuekan’ 林辰藏淪陷區期刊 : 《中和》月刊 (The journal Concordia published under the occupation in Lin Chen's collection). LuXun yanjiu yuekan 魯迅研究月刊 (Lu Xun Research Monthly) 5 (2007): 70-75.

Yuan Yidan 袁一丹. 'Yinwei xiuci: Beiping lunxian shiqi wenren xuezhe de biaoda celüe' 隱微修辭：北平淪陷時期文人學者的表達策略 (Esoteric writing: the literati and scholars' strategies of expression in occupied Beiping), Zhongguo xiandai wenxue yanjiu congkan 中國現代文學研究叢刊 (Modern Chinese Literature Studies) 1 (2014): 1-18.

Yuan Yidan. 'Yidai tongshi yu yimin nitai' 易代同時與遺民擬態 (The contemporaneity of dynastic changes and the mimicry of remnant loyalists), Wenxue pinglun 文學評 論 (Literature Review) 3 (2015): 81-91. 